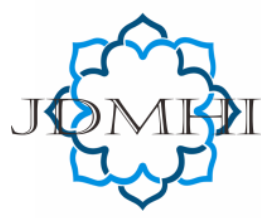

email: jdmhi@walisongo.ac.id

Journal of Digital Marketing and Halal Industry

ISSN: 2716-4810 (print) ISSN: 2716-4802 (online)

\title{
Impact of Service Quality and Application of Sharia Principles on Consumer Intention of Sharia Hotel
}

\author{
Al Haq Kamal1, Abdul Salam², Ageng Asmara Sani3 ${ }^{3}$, Prabumadya \\ Brojosetami ${ }^{4}$ Tyagita Dianingtyas Sudibyo ${ }^{5}$ \\ 1,2,3,4 Faculty of Islamic Religion Alma Ata University, Yogyakarta, Indonesia \\ ${ }^{5}$ Faculty of Economics and Business Alma Ata University, Yogyakarta Indonesia
}

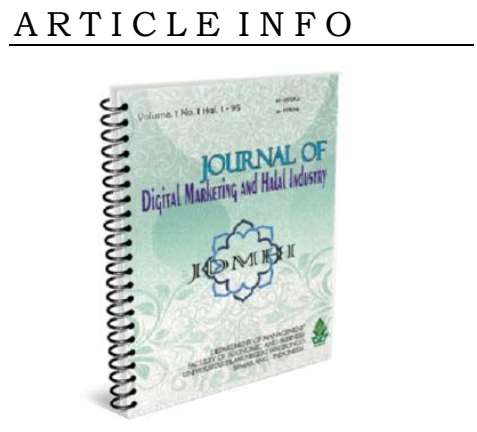

Article history:

Received 11 June 2021

Accepted 22 September 2021

Published 30 October 2021

Keywords:

Halal Product, Mandatory,

Regulatory Impact Analysis

(RIA)
A B S T R A C T

This research aims to measure and analyze the influence of quality of service and the application of sharia principles to consumers at Syariah Hotel Limaran. The data used in this study is primary data. Although the method of data collection used is simple random sampling with a sample of 60 customers of Syariah Limaran hotel, this research also uses observation, questionnaires, and documentation. The data analysis techniques in this study are descriptive analysis tests, multiple linear regression tests, partial ( $\mathrm{t}$ ) tests, simultaneous tests (f), and determinant coefficients ( $\mathrm{r} 2$ ). Results obtained based on $t$ and $f$ test results produce a significant value of 0.05 . Then the $\mathrm{R}$ Square value of 0.461 indicates that an independent variable can affect dependent variables by $46.10 \%$. While other variables outside this study explain the remaining $53.90 \%$. The study concludes that the quality of service and the application of sharia principles affect consumers' intention in Sharia hotels.

@2021 Journal of Digital Marketing and Halal Industry

\section{Introduction}

The Sharia Economic Industry is increasing in the business world, including the service sector. Services that apply sharia principles in running a business, such as Islamic travel, halal culinary, and business in the tourism sector, must comply with the concepts and procedures of sharia (Izza, 2018). The Muslim market share is huge, especially in the ASEAN market with the largest Muslim population (Basalamah, 2011). According to (Baharuddin \& Hasan, 2018), the Islamic economic sector has experienced

* Corresponding author.email: kamal.alhaq@almaata.ac.id DOI: http://dx.doi.org/10.21580/jdmhi.2021.3.2.8269 
growth and concerns many people in lifestyle products, namely halal tourism.

Indonesia is starting to look to the tourism sector as one of the state's revenues. Data from the central statistical agency in 2018 stated that the total number of domestic tourists traveling to local destinations was 303.40 million trips, an increase of $12.37 \%$ from the previous year, which amounted to 270.00 . While the total expenditure during 2018 reached 291.02 trillion rupiahs, an increase of $17.89 \%$ compared to the previous year, which reached 246.85 trillion rupiahs (BPS, 2018).

\section{Figure 1.}

National Tourist Statistics Distribution of Number National

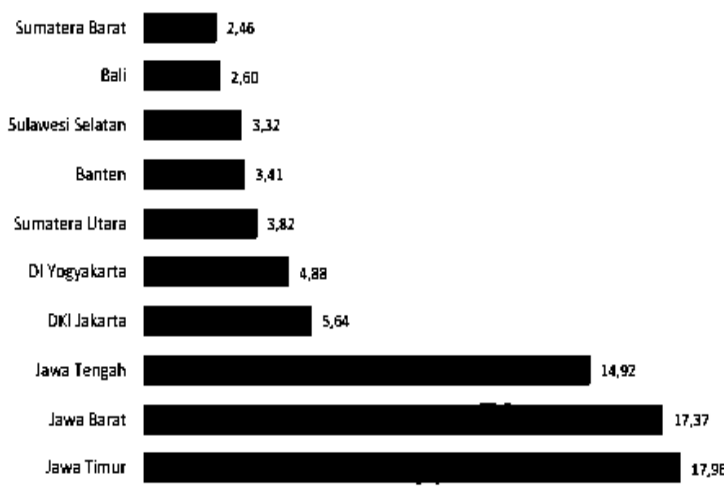

Based on information from the results of the 2018 survey of domestic tourists, the number of trips for domestic tourists is dominated by East Java province by $17.55 \%$ and West Java by $17.54 \%$, while domestic tourist destinations from 303.40 million trips are $17.96 \%$ for their destinations to East Java and $17.37 \%$ to West Java and Yogyakarta. This research highlights that it gets $2.59 \%$ of domestic tourists by the province of origin and $4.88 \%$ as tourist destinations for domestic tourists. The travel data reflects the potential for tourism-related businesses such as food, tourism locations, tours and travel, and lodging (BPS, 2019).
Figure 2.

Distribution Of Number National Tourist Trips By Province Of Destination

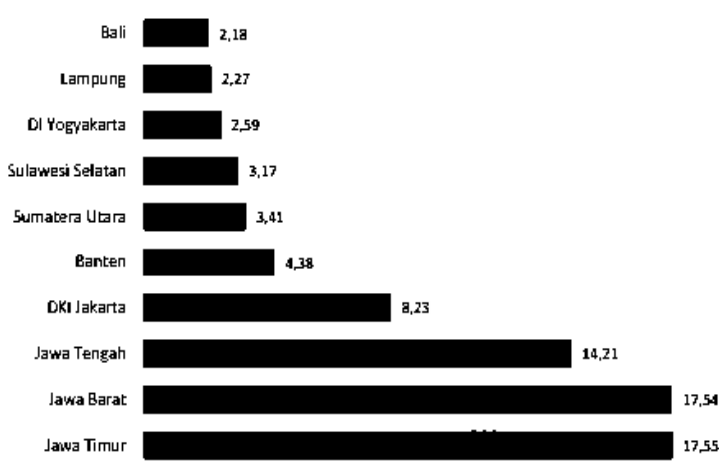

The lodging business is a reasonably advanced business activity globally and in Indonesia in particular. Lodging business opportunities are also getting bigger based on the tourism potential above. In supporting a tour, there must be lodging as a place to rest (Kavanillah \& Ridlwan, 2018). Lodging or hotels are currently always needed by tourists on vacation to a city. Those who have built hotels have provided comfort to staying customers so they can rest comfortably beyond their own homes (Widyarini, 2013). One of the Sharia hotels that uphold Islamic values in their business practices is Hotel Limaran Syariah Yogyakarta.

Hotel Limaran is unique, which differentiates it from other hotels. Hotel Limaran is an Islamic inn. One thing that distinguishes Hotel Limaran from other hotels is that the services and facilities provided reflect Islamic values and have religious nuances. As a simple example, all hotel employees wear clothes covering their genitals. The hotel also provides halal food and drinks and the availability of religious facilities in each room (www.hotellimaran.com, 2019).

Furthermore, if you look at the data above, the total visitors to Hotel Limaran Syariah are 
mostly in July-August and NovemberDecember, which are the peak and holiday seasons. So it is natural that at that time the number of guests staying had increased. Based on this background, the researcher intends to further research "The Effect of Service Quality and Application of Sharia Principles on Consumer Intention in Sharia Hotels" (Case Study of Hotel Limaran Syariah Yogyakarta). The results of this study can provide an overview of the activities and development of Islamic hotels in Yogyakarta.

\section{Literature Review}

Sharia hotels are included in the business sector that distributes services in the form of lodging (Sugeng \& Basmar, 2020). Sharia hotels are one of the accommodation facilities for Muslim tourists to stay, which affects fulfilling the needs of tourists (Lestari \& Sujana, 2019). A Sharia Hotel Business is a hotel business whose implementation must meet the criteria for a Sharia Hotel Business as referred to in the Regulation of the Minister of Tourism and Creative Economy Number 2 of 2014. Therefore, Sharia hotels are expected not only to comply with sharia principles but also to provide good service. Every consumer will need a comfortable place to clean. Every consumer always wants the best in every service he uses because it is his right (Alridho et al., 2019).

(Suharno, 2007) "Quality of Service in Malang, East Java, Hotel Graha Cakra based on Customer Satisfaction." The independent variable is service quality. The dependent variable is customer satisfaction. The method used is non-probability sampling through simple random sampling. This study indicates that the variable reliability, responsiveness, assurance, empathy, tangibles have a significant effect on customer satisfaction with the services provided by hotel management to form perceptions.

(Nusa, 2014) examines the effect of applying Shari'ah principles and service quality on customer satisfaction and loyalty of shari'ah hotels". The independent variable is applying the principles of sharia, service quality. The dependent variable is customer satisfaction, hotel loyalty. The analytical method used is multiple regression analysis and simple linear regression. This study indicates that the quality of the interaction and the quality of the results of Islamic principles can positively affect consumer loyalty. Nisa \& MA (2018) use probability sampling techniques with simple random sampling totaling 80 respondents consisting of 50 respondents from The Amrani Hotel and 30 from Hotel Arini. concluded that service quality has a positive and significant effect on customer satisfaction

Syahril (2015) examines the effect of customer service and facilities provided by hotels on visitor intention to stay (Case Study at Hotel Semarang Semesta) ". The independent variable is the influence of customer service, facilities. The dependent variable is visitor intention. The method used is simple random sampling. That is, samples taken randomly from all population members have the same chance of being selected as the sample. The results of this study indicate a significant and positive effect on visitor intention.

\section{Research Method}

Research is a type of quantitative research so that research problems can be solved using statistics or other means of quantification or measurement. This research is also included in field research, namely direct research conducted in the field or respondents. 
This research was conducted at the Limaran Syariah Hotel Yogyakarta on Jalan Taman Siswa No.33 Wirogunan, Mergangsan Yogyakarta. The study was conducted on 6-20 May 2019. The population in this study was unknown, so the researchers used the research sampling technique using simple random sampling because the data collection time only lasted 14 days. They were obtained by customers who visited Hotel Limaran Syariah on May 6-20, 2019, namely 60 visitors, so that they were made respondents in this study.

The research instrument used was informed consent, namely when asking the respondent's willingness to participate as research subjectsself-identity questionnaire to determine the characteristics sample (gender, age, latest education, occupation). Then, the data is processed using SPSS 20, the validity test is carried out to determine how valid the data is.
After that, the reliability test was carried out as a tool for data collection because the instrument was good. The data analysis technique in this research uses descriptive analysis and multiple linear regression analysis.

\section{Result and Discussion}

\section{Characteristics of Respondents}

A description of the characteristics of the respondents is needed. The characteristic description is based on gender, age, and education level. Table 1 shows that the number of respondents with male gender is greater than that of female, namely by $55 \%$ versus $45 \%$. This shows that men are more potential in using accommodation services, that quality of services for implementing sharia principles at Hotel Limaran Syariah.

\section{Table 1.}

Characteristics of Respondents Based on Gender

\begin{tabular}{cccc}
\hline Number & Gender & Total & Percentage \\
\hline 1. & Male & 33 & $55 \%$ \\
2 & Female & 27 & $45 \%$ \\
\hline & Total & 60 & $100 \%$ \\
\hline
\end{tabular}

Table 2.

Characteristics of Respondents by Age

\begin{tabular}{|c|c|c|c|}
\hline Number & Age & Total & Percentage \\
\hline 1. & Under 20 & 2 & $3,33 \%$ \\
\hline 2. & $21-29$ & 14 & $23,33 \%$ \\
\hline 3. & $30-39$ & 23 & $38,33 \%$ \\
\hline 4. & $40-49$ & 13 & $21,66 \%$ \\
\hline \multirow[t]{2}{*}{5.} & More Than 50 & 8 & $13,33 \%$ \\
\hline & Total & 60 & $100 \%$ \\
\hline
\end{tabular}

Based on table 2, customers who are under 20 are 3,33\%, customers aged 21-29 years are $23,33 \%$, while respondents aged 30-39 are
$38,33 \%$, while respondents aged $40-49$ are $21,66 \%$ and the rest of respondents aged 50 and over amounted to $13,33 \%$. Thus, it can be 
concluded that most Hotel Limaran Syariah consumers are aged 30 to 39 years.

Table 4.3 shows that most of the respondents have private employee jobs, namely $45 \%$, while civil servants are $23.33 \%$, compared to entrepreneurs/traders whose results are $21.66 \%$ and the rest are students as much as $10 \%$.

\section{Table 3.}

Characteristics of Respondents by profession

\begin{tabular}{|c|c|c|c|}
\hline Number & Profession & Total & Percentage \\
\hline 1. & Government Employees & 14 & $23,33 \%$ \\
\hline 2. & Private company employees & 27 & $45 \%$ \\
\hline 3. & Entrepreneur / Trader & 13 & $21,66 \%$ \\
\hline \multirow[t]{2}{*}{4.} & Student & 6 & $10 \%$ \\
\hline & Total & 60 & $100 \%$ \\
\hline
\end{tabular}

\section{Data analysis}

To find out that the instruments in this study can be trusted, the validity and reliability tests are carried out first.

\section{Validity test}

The validity test is necessary for a study, especially for a questionnaire to obtain data. This test is conducted to determine the validity of the data. An instrument is valid if it measures what is being measured or can reveal data from the precise variables accurately. The size and the low validity of the instrument can indicate how much the collected data deviates from the objective description of the variable in question.

Validity testing can be done by correlating the item score with the total score using the Pearson Correlation (Product Moment) technique using SPSS 20. The test criteria is stated if the correlation coefficient $(r)>$ table correlation ( $\mathrm{r}$ table) means the item is declared valid or able to measure the variable be measured. For more details, it can be stated in the following table:

\section{Table 4.}

Validity Test

\begin{tabular}{lcccc}
\hline \multicolumn{1}{c}{ Variable } & Question & $\begin{array}{c}\text { Correlation } \\
\text { Coefficient }\end{array}$ & R table & Description \\
\hline Quality of & X1.1 & 0,380 & 0,2108 & Valid \\
Service (X1) & X1.2 & 0,621 & 0,2108 & Valid \\
& X1.3 & 0,584 & 0,2108 & Valid \\
& X1.4 & 0,452 & 0,2108 & Valid \\
& X1.5 & 0,382 & 0,2108 & Valid \\
& X1.6 & 0,524 & 0,2108 & Valid \\
& X1.7 & 0,699 & 0,2108 & Valid \\
& X1.8 & 0,455 & 0,2108 & Valid \\
\hline
\end{tabular}


Vol. 3, No. 2 (2021) 165-178

\begin{tabular}{lcccc}
\hline & X1.9 & 0,441 & 0,2108 & Valid \\
& X1.10 & 0,478 & 0,2108 & Valid \\
& X1.11 & 0,252 & 0,2108 & Valid \\
& X1.12 & 0,572 & 0,2108 & Valid \\
& X1.13 & 0,702 & 0,2108 & Valid \\
& X1.14 & 0,642 & 0,2108 & Valid \\
& X1.15 & 0,424 & 0,2108 & Valid \\
& X1.16 & 0,482 & 0,2108 & Valid \\
& X1.17 & 0,377 & 0,2108 & Valid \\
\hline Application & X2.1 & 0,499 & 0,2108 & Valid \\
of Sharia & X2.2 & 0,709 & 0,2108 & Valid \\
Principles & X2.3 & 0,670 & 0,2108 & Valid \\
(X2) & X2.4 & 0,581 & 0,2108 & Valid \\
& X2.5 & 0,690 & 0,2108 & Valid \\
& X2.6 & 0,682 & 0,2108 & Valid \\
& X2.7 & 0,789 & 0,2108 & Valid \\
& X2.8 & 0,396 & 0,2108 & Valid \\
& X2.9 & 0,342 & 0,2108 & Valid \\
& X2.10 & 0,564 & 0,2108 & Valid \\
& X2.11 & 0,348 & 0,2108 & Valid \\
\hline Consumer & Y1.1 & 0,672 & 0,2108 & Valid \\
Intention (Y) & Y1.2 & 0,723 & 0,2108 & Valid \\
& Y1.3 & 0,702 & 0,2108 & Valid \\
& Y1.4 & 0,645 & 0,2108 & Valid \\
& Y1.5 & 0,549 & 0,2108 & Valid \\
& Y1.6 & 0,593 & 0,2108 & Valid \\
& Y1.7 & 0,678 & 0,2108 & Valid \\
& Y1.9 & 0,561 & 0,2108 & Valid \\
\hline
\end{tabular}

The validity test results of service quality and the application of Islamic principles to consumer intentions of Islamic hotels show that the r-value of the variable for the significant level of 0.5 is 0.2108 . Moreover, based on table 4.4 above, it can be seen that all sector statements regarding X1, X2, and Y have $r$ count greater than $r$ table. So it can be concluded that the independent variable is valid and can be used as a measuring tool in research.

\section{Reliability Test}

A measuring instrument can be said to be reliable and trusted if the instrument used is stable, reliable, and can be used in forecasting. This study will conduct testing using the Cronbach Alpha method in the SPSS 20 program. The variable can be reliable if the Alpha coefficient is from 0.60 . 
Table 5. Reliability Test

\begin{tabular}{ccc}
\hline Variable & Cronbach's Alpha & N of Items \\
\hline Quality of Service (X1) & 813 & 17 \\
Application of Sharia Principles (X2) & 796 & 11 \\
Consumer Intention (Y) & 817 & 9 \\
\hline
\end{tabular}

Source: Primary Data Processed, 2019

The reliability test results of the independent and dependent variables can be seen from the output reliability statistics, where the test results obtained from the Cronbach's Alpha value are more than 0.60 . It can be concluded that the measuring instrument in the study is reliable.

Table 6.

Descriptive statistics

\begin{tabular}{llcccc}
\hline Research variable & N & Mean & Min & Max & SD \\
\hline Quality of Service (X1) & 60 & 65,28 & 54 & 79 & 5,434 \\
Application of Sharia Principles (X2) & 60 & 42,87 & 36 & 52 & 3,771 \\
Consumer Intention (Y) & 60 & 35,42 & 26 & 43 & 3,761 \\
\hline
\end{tabular}

Based on the table above, the service quality of the 60 samples has an average value (mean) of 65.28 , a minimum value of 54 , a maximum value of 79 , and a standard deviation value of 5.434. From these data, it can be said that the average value is greater than the standard deviation value, which means that the data in this study are varied.

Based on the application of sharia principles, the 60 samples have an average (mean) value of 42.87 , a minimum value of 36 , a maximum value of 52, and a standard deviation value of 3.771. Therefore, from the data above, it can be said that the average value is greater than the standard deviation value, which means that the data in this study are varied.

\section{Descriptive Analysis}

It aims to describe and provide an overview of the object under study through sample and population data as it is, without analyzing and general conclusions.
Based on the table above, the amount of consumer intention from the 60 samples has an average value (mean) of 35.42 , a minimum value of 26 , a maximum value of 43 , and a standard deviation value of 3.761 . Therefore, from that data, it can be said that the average value is greater than the standard deviation value, which means that the data in this study are varied.

\section{Hypothesis Test}

H1: Service quality affects consumer intention in Islamic hotels.

H2: the application of sharia principles affects the service quality of sharia hotels. 
Table 7.

Multiple Regression Test Results

\begin{tabular}{|c|c|c|c|c|c|}
\hline \multirow[t]{2}{*}{ Model } & \multicolumn{2}{|c|}{$\begin{array}{l}\text { Unstandardized } \\
\text { Coefficients }\end{array}$} & \multirow{2}{*}{$\begin{array}{l}\text { Standardized } \\
\text { Coefficients } \\
\text { Beta }\end{array}$} & \multirow[t]{2}{*}{$\mathrm{T}$} & \multirow[t]{2}{*}{ Sig } \\
\hline & $\mathrm{B}$ & Std. Error & & & \\
\hline 1 (Constant) & -2.231 & 5.533 & & -.403 & .688 \\
\hline X1 & .387 & .069 & .559 & 5.632 & .000 \\
\hline $\mathrm{X} 2$ & .289 & .099 & .290 & 2.922 & .005 \\
\hline
\end{tabular}

Based on the table above, there is a relationship between service quality variables (X1), application of sharia principles (X2), to consumer intentions $(\mathrm{Y})$, with the dual strategy equation:

$$
\mathrm{Y}=-2.231+0,387 \mathrm{X} 1+0,289 \mathrm{X} 2
$$

A constant value of $-2,231$ states that if the service quality variable, the application of sharia principles, is equal to zero, then the constant value has a positive impact indicating an increase in consumer intention by $-2,231$.

The regression coefficient (b1) for $\mathrm{X} 1$ is positive at 387. This means that if the coefficient value of the other independent variables is constant, adding the service quality variable by $1 \%$ will increase consumer intention to use Islamic hotels by 387. Therefore, the coefficient is positive. Then the service quality positively influences consumer intentions of Islamic hotels.

\section{Table 8.}

Partial Test Result ( $t)$
The regression coefficient (b2) for X2 is positive at 289. This means that if the coefficient value of other independent variables is constant, adding the variable applying sharia principles by $1 \%$ will increase consumer intention to use Islamic hotels by 289 . If the coefficient is positive, then applying the principle Islamic principles positively influences consumer intentions of Islamic hotels.

\section{Partial Test $(\mathrm{t})$}

The $t$ test aims to determine the effect of the independent variables consisting of service quality and application of sharia principles on consumer intention to use sharia hotels partially. With decision making:

If the value is Sig. $<0.05$ or $t$ count $>t$ table, then there is an effect of variable $X$ with variable Y. If the value is Sig. $>0.05$ or t count $<\mathrm{t}$ table, so variable $\mathrm{X}$ has no effect with variable Y.

\begin{tabular}{ccc}
\hline Model & $\mathrm{T}$ & Sig \\
\hline Constanta & -.403 & .688 \\
X1 & 5.632 & .000 \\
X2 & 2.922 & .005 \\
\hline
\end{tabular}

DOI: http://dx.doi.org/10.21580/jdmhi.2021.3.2.8269

$172 \mid \mathrm{P}$ a g e 
Based on the values above, it can be concluded:

The Sig. for the effect of $\mathrm{X} 1$ on $\mathrm{Y}$ is equal to $0.000>0.5$ and the value of $t$ count is 5.632> 2.002 so it can be concluded that $\mathrm{H} 1$ is acceptable, meaning that there is an influence between the variable quality of service on consumer intention to use Islamic hotels.

The Sig. for $\mathrm{X} 2$ to $\mathrm{Y}$ is $0.005<0.5$ and the $\mathrm{t}$ value is $2.922>2.002$ so it can be concluded that $\mathrm{H} 2$ is accepted. This means that there is an influence between the variables of applying the principles of sharia to the intention of consumers to use Islamic hotels.

\section{Simultaneous Test (f)}

The $F$ test is used to determine the independent variables' effect (simultaneously) on the dependent variable. The results of the $\mathrm{F}$ test can be seen in the ANOVA table output in the table using a probability of $5 \%$ or 0.05 .

\section{Table 9.}

Simultan Test

\begin{tabular}{llccccc}
\hline & Model & Sum Squares & Df & Mean Square & F & Sig \\
\hline \multirow{2}{*}{1} & Regression & 385.007 & 2 & 192.503 & 24.407 & $.000^{\mathrm{b}}$ \\
& Residual & 449.576 & 57 & 7.887 & & \\
\cline { 2 - 6 } & Total & 834.583 & 59 & & & \\
\hline
\end{tabular}

a. Dependen Variabel Y

b. Predictors (Constant) X2,X1

Under the condition:

a. If the value is Sig. $<0.05$ or $f$ count $>f$ table, then the effect of variable $X$ can simultaneously affect variable $Y$

b. If the value is Sig. $>0.05$ or $f$ count $>$ $\mathrm{f}$ table, so there is no simultaneous influence on variable $\mathrm{Y}$

Based on the output above, the significant value for the simultaneous influence of X1 and $\mathrm{X} 2$ on $\mathrm{Y}$ is $0.000<0.5$ and the $f$ value is $24.407>2.76$ so it can be concluded that $\mathrm{H} 3$ is accepted, which means the simultaneous influence of X1 and X2 on Y.

\section{Determination Test (R2)}

The determination test is used to determine the percentage contribution of the influence of service quality variables and the implementation of Islamic principles together on consumer intention (Y). The R2 test is carried out with the help of SPSS which can be seen in the following table:

Table 10. Destination Test Results Model Summary

\begin{tabular}{ccccc}
\hline Model & R & R Square & Adjusted Square & R. Std. Error of the Estimate \\
\hline 1 & $.679^{\mathrm{b}}$ & .461 & .442 & .2 .808 \\
\hline
\end{tabular}

Based on the table above, it can be seen that the results of the determination test in the summary 
model output from the results of multiple regression analysis in the adjusted $\mathrm{R}$ square column is .461. This shows that the effect of variables X1 and X2 simultaneously on variable $\mathrm{Y}$ is $46.2 \%$.

\section{Discussion}

Hotel Limaran Syariah is located in the center of Yogyakarta. It is precisely $0 \mathrm{~km}$ from the city of Yogyakarta, so customers can easily choose tourist locations. Hotel Limaran Syariah is located in the main tourist center route and adjacent to other tourist attractions such as the Vredeburg Fort Building, the Presidential Palace, Kraton, North Square, and Beringharjo Traditional Market, approximately 5 minutes walk from Hotel Limaran Syariah. Hotel Limaran Syariah has supporting facilities. The hotel has a beautiful environment with large, shady trees, adding to the comfort and coolness of your trip in the city of Yogyakarta with traditional and modern nuances.

Based on the research and observation, several sections will be discussed in the variable variables taken by researchers at Hotel Limaran Syariah. Here the researcher will discuss the quality of service and the application of the principles of sharia in Hotel Limaran Syariah. There are several indicators of Service Quality at Hotel Limaran Syariah, namely Reception, Restoration, Housekeeping, Food, and Beverage.

The receptionist is in charge of receiving guests (in a company, hotel, office). The reception at Hotel Limaran Syariah is located at the hotel's front entrance. Receptionists at Hotel Limaran Syariah have excellent skills, such as responding to guests very well, such as communicating well in a straightforward, effective, efficient and friendly way so that guests do not feel disappointed even though their wishes are not fulfilled. In welcoming guests who come, the reception employees are always friendly. In answering consumer questions, the reception employees use polite and polite language and provide information and explanations. The reception employees are friendly, gentle, and polite to have a good impression. Good for consumers who will stay at Hotel Limaran Syariah.

A restoration is a place that provides food and drinks for guests to consume, the restoration is located in the western part of the hotel on the 1st floor. Restoration employees at Hotel Limaran Syariah in serving guests have a good and friendly attitude, the service is not inferior to the receptionist department. Restoration employees at Hotel Limaran Syariah also provide free food during breakfast or breakfast time. With a comfortable and peaceful atmosphere, consumers can enjoy eating with satisfaction. Employees in the restoration section work quickly and agile in serving the menu ordered by consumers at Hotel Limaran Syariah.

Housekeeping is a part of the hotel that handles matters related to cleanliness and tidiness. Housekeeping employees at Hotel Limaran Syariah, in carrying out their duties quickly and precisely in arranging rooms are also excellent and agile in cleaning rooms and other areas in the hotel. Housekeeping employees are responsive to what consumers want and friendly to consumers. The housekeeping employee understands the duties he should do to satisfy consumers with the service provided.

Food and Beverage is part of the hotel responsible for the needs of food and beverage services. The food and beverage menu at Hotel Limaran Syariah is provided with halal food and drinks and good for health. The food and 
beverage menu provided does not contain harmful substances and preservatives and is protected from pollution. The food and drinks are presented attractively and neatly. With nuanced Islamic hospitality, the food and beverage section of the Limaran hotel has halal food and drinks so that it is suitable for consumption by Muslims and non-Muslims.

The application of sharia principles at Hotel Limaran Syariah is the availability of worship facilities and the elimination of facilities contrary to Islamic law. For example, at Hotel Limaran Syariah, there is a direction of the Qibla in each room, there is a good place of worship. In addition to worship, it is also equipped with a good ablution place. Prohibition of staying in one room for couples who are not husband and wife, Hotel Limaran Syariah applies selective rules for each consumer who will stay. Consumers who are not married couples cannot stay in one room. Furthermore, the obligation to cover aurat for hotel employees is that all Hotel Limaran Syariah employees wear closed clothes or cover their genitals following Islamic law. There are no female employees who dress sexy.

Based on the effect of service quality on consumer intentions to use sharia hotels when viewed from the results of the $\mathrm{R}$ Square test, it can be concluded that the variable service quality and application of sharia principles has an effect of $46.1 \%$ while $53.9 \%$ is influenced by other variables not examined by the research method.

The effect of service quality on consumer intention to use Islamic hotels when viewed from the results of the $f$ test shows the results with a value of 24.407 with a value of Sig. 0.000 indicates that the calculated $\mathrm{f}$ value is greater than $\mathrm{f}$ table 2.76 with the Sig. it is lower than 0.05. With this matter ii then Ho is accepted and $\mathrm{Ha}$ is rejected. It can be interpreted that the quality of service and the application of sharia principles simultaneously have a significant influence on the intention of sharia hotel consumers.

The intention of sharia hotel consumers, when viewed from the t-test results, shows the influence of service quality variables on consumer intentions of Islamic hotels of 5,632 with a Sig. $0.000<0.05$, so in this case, it shows that the value of $t$ is greater than the table so that it shows that $\mathrm{Ha}$ is accepted Ho is rejected. This means that the service quality variable affects the consumer's intention to use Islamic hotels.

The effect of applying the principles of sharia principles on the intention of sharia hotel consumers when viewed from the $t$ value of 2.922 with a significant value of 0.05 , which means that the $t$ value is greater than the $t$ table value of 2.002 with the same significant value of 0.05 , this shows that the variable of applying sharia principles affect the intention of consumers to use Islamic hotels.

The effect of service quality and application of Islamic principles on consumer intentions of Islamic hotels shows a significant effect as evidenced by the analysis of variance, which shows R Square of 40.61 with a probability value of 0.000 . Because the probability value is smaller than the value of 0.05 and based on the multiple regression equation obtained where the regression coefficients $\mathrm{X} 1$ and $\mathrm{X} 2$ are positive, it can be interpreted that there is a positive influence between service quality and application of sharia principles on consumer intentions of Islamic limaran hotels. Based on the results of the simultaneous test or $\mathrm{f}$ test, it can be interpreted that the quality of service and application of the principles of sharia. There is a consumer intention to use Islamic hotels 
simultaneously with a positive impact with a significant value of 0.000 less than 0.05 or $f$ count 24.407 is greater than $f$ table 2.76. From the question formulation of the problem that the quality of service and the application of Islamic principles can simultaneously influence the intention of consumers to use Islamic hotels.

The same result was also reported by (Aptaguna $\&$ Pitaloka, 2016), which states that the service quality variable significantly affects service purchase intentions. This study is in line with (Syahril, 2015) research which shows the influence of employee services and facilities on visitors who intend to stay overnight. This is because employee service and good facilities will lead to satisfaction for staying visitors. The same thing was also expressed by (Huda et al., 2018), which stated that consumers choose sharia hotels because of the services provided by friendly sharia hotels, have a polite and attractive appearance, have good behavior, and have good behavior honest behavior and are fast responsive.

\section{Conclusion}

Based on the results of the discussion and the results of previous researchers, the researchers concluded that the quality of service and the application of Islamic principles had a positive impact on consumer intentions to use Hotel Limaran Syariah. With the best service quality provided at Hotel Limaran Syariah, the greater the consumer's intention to use the hotel. Furthermore, Shariah and the application of sharia principles the better with the application or atmosphere. Therefore, more consumers intend to use sharia hotels. This is because employee service and good facilities will lead to satisfaction for staying visitors. In addition, consumers tend to choose sharia hotels because the services provided by sharia hotels are friendly, have a polite and attractive appearance, have good behavior, have honest behavior and are fast responsive.

\section{Suggestion}

Based on these results, in the future, sharia hotels need to pay attention to service quality and optimize the implementation of sharia principles so that consumer interest in sharia hotels will increase.

\section{References}

Abd. Rohman Fahruddin. (2019). Implementasi Pengelolaan Makanan Halal Di Indonesia. At-Tasharruf; Jurnal Kajian Ekonomi Dan Bisnis Syariah, 1(1), 37-46.

https://doi.org/10.32528/at.v1i1.2488

Agus, P. A. (2017). Kedudukan Sertifikasi Halal Dalam Sistem Hukum Nasional Sebagai Upaya Perlindungan Konsumen Dalam Hukum Islam. Amwaluna: Jurnal Ekonomi Dan Keuangan Syariah, 1(1), 150-165. https://doi.org/10.29313/amwaluna.v1i 1.2172

Ali, M. (2016). Konsep Makanan Halal dalam Tinjauan Syariah dan Tanggung Jawab Produk Atas Produsen Industri Halal. AHKAM : Jurnal Ilmu Syariah, 16(2), 291306. https://doi.org/10.15408/ajis.v16i2.445 9

Alisjahbana, A. S. (2012). Pengembangan Dan 
Implementasi Metode Regulatory Impact Analysis (RIA) Untuk Menilai Kebijakan (Peraturan Dan Non Peraturan) Di Kementerian Ppn/Bappenas. Biro Hukum Kementerian PPN/Bappenas. http://jdih.bappenas.go.id/monografi/d etailmonografi/1897

Ariny, B. D., \& Nurhasanah. (2020). Dampak Positif Undang-Undang Nomor 33 Tahun 2014 Tentang Jaminan Produk Halal Dalam Menciptakan Sistem Jaminan Produk Halal Di Indonesia. Syarie: Jurnal Pemikiran Ekonomi Islam, 3(2), 198-218. https://stai-binamadani.ejournal.id/Syarie/article/view/204/170

Charity, M. L. (2017). Jaminan Produk Halal Di Indonesia. Jurnal Legislasi Indonesia, Vol.14(1), 99-107. https://ejurnal.peraturan.go.id/index.php/jli/issu e/view/9

Faridah, H. D. (2019). Halal certification in Indonesia; history, development, and implementation. Journal of Halal Product and Research, 2(2), 68. https://doi.org/10.20473/jhpr.vol.2issue. 2.68-78

IBTimes.ID. (2020, April 8). Data Populasi Penduduk Muslim 2020: Indonesia Terbesar di Dunia. PT Litera Cahaya Bangsa. https://ibtimes.id/data-populasipenduduk-muslim-2020-indonesiaterbesar-di-dunia/

Istikomah. (2019). Peluang Dan Tantangan Implementasi UU JPH. At-Tasharruf; Jurnal Kajian Ekonomi Dan Bisnis Syariah, 1(1), $18-28$. https://doi.org/10.32528/at.v1i1.2486

Nasokah, N. (2008). Implementasi Regulatory Impact Assessment (RIA) Sebagai Upaya Menjamin Partisipasi Masyarakat Dalam
Penyusunan Peraturan Daerah. JURNAL HUKUM IUS QUIA IUSTUM, 15(3), 443-458.

https://doi.org/10.20885/iustum.vol15.i ss $3 . \operatorname{art} 5$

OECD. (2005). Recommendation of the Council on Improving the Environmental Performance of Government. 5-6. https://legalinstruments.oecd.org/en/ins truments/OECD-LEGAL0278\#mainText

OECD. (2008). Building an Institutional Framework for Regulatory Impact Analysis (RIA). Building an Institutional Framework for Regulatory Impact Analysis (RIA). https://doi.org/10.1787/978926405001 3-en

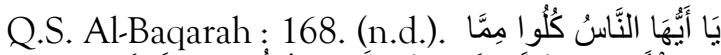

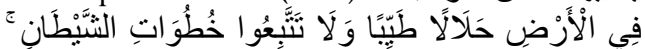

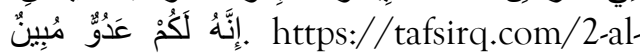
baqarah/ayat-168

Sayekti, N. W. (2014). Jaminan Produk Halal dalam Perspektif Kelembagaan. Jurnal Ekonomi Kebijakan Publik, 5(2), 193-209. https://doi.org/10.22212/jekp.v5i2.84

Septiani, D., \& Ridlwan, A. A. (2020). The Effects of Halal Certification and Halal Awareness on Purchase Intention of Halal Food Products in Indonesia. Indonesian Journal of Halal Research, 2(2), 55-60. https://doi.org/10.15575/ijhar.v2i2.665 7

UU Nomor 33 Tahun 2014. (2014). Tentang Jaminan Produk Halal. BPJPH.

Warto, W., Rofiq, A., \& Mashudi, M. (2019). Peranan Kaedah-Kaedah Fundamental Kebahasaan Dalam Penetapan Produk Halal. Indonesia Journal of Halal, 2(1), 10. 
https://doi.org/10.14710/halal.v2i1.431

8 